\title{
INTERACTIONS Between SOYBeAN AND WeEdS IN A Replacement Series System, Considering THe EfFects of WATER Stress ${ }^{1}$
}

\author{
Interações entre Soja e Plantas Daninhas em um Sistema de Série Substitutivas, Considerando \\ os Efeitos do Estresse Hídrico
}

\author{
VIVIAN, R. ${ }^{2}$, DOURADO-NETO, D. ${ }^{3}$, FILHO, R.V. ${ }^{3}$, SILVA, A.A. ${ }^{4}$, FRANCO, R.B. ${ }^{5}$, and \\ CORREA, S.T.R. ${ }^{3}$
}

\begin{abstract}
Due to the increase of water deficiency in many farm regions and its meaning on weed interference, competitive interactions between soybean and three weeds were evaluated under water stress (20 to 40 days after transplanting) and no stress conditions. Three independent experiments were carried out in a growth chamber, being each one composed by the weeds Alternanthera tenella, Tridax procumbens or Digitaria ciliaris, along with the crop, in which soil water condition and plant composition effects were evaluated while in competition. A replacement series system was used, including both monoculture of each species and a mixture with a ratio of $50 \%$ between weed and soybean. A completely randomized design was used in factorial arrangement, with treatments distributed in three levels for plant composition factor (soybean and weeds monocultures, in addition to the soybean + weed mixture) and two levels for the water factor (with or without stress), amounting six treatments in each experiment. Soybean dry mass was higher than weed dry mass, when growing without water stress. However, under water stress conditions, the dry mass of soy was reduced in all experiments, mainly in the $D$. ciliaris comparative experiment. Water restriction was also significant in the plants' photosynthesis reduction in most of the experiments, reducing leaf area duration and efficiency of water use. Analysing all variables shows greater weed tolerance than soybean when submitted to water deficit and with distinct changes of their interactions and mechanism of competition, in each experiment.
\end{abstract}

Keywords: Glycine max, drought, Alternanthera tenella, Tridax procumbens, Digitaria ciliaris.

RESUMO - Devido ao aumento da deficiência hídrica em muitas regiões agrícolas e sua importância na interferência de plantas daninhas, avaliaram-se as interações competitivas de soja com três espécies de plantas, sob condições normais de crescimento ou com deficiência hídrica temporária (20-40 dias após transplante). Os três experimentos foram realizados em câmara de crescimento, com as espécies Alternanthera tenella, Tridax procumbens ou Digitaria ciliaris, juntamente com a cultura, avaliando-se os efeitos do conteúdo de água no solo e da composição de plantas, na capacidade competitiva de cada espécie. Utilizou-se o sistema de séries substitutivas, abrangendo o monocultivo e a mistura na proporção de 50\% entre cada planta daninha e a soja. Utilizou-se o delineamento inteiramente casualizado, em esquema fatorial, com tratamentos distribuídos em três níveis para o fator composição de plantas (monocultivos de soja e das plantas daninhas, além da mistura soja + planta daninha) e dois niveis para o fator deficiência hidrica (sem ou com deficiência), totalizando seis tratamentos em cada experimento. A massa de matéria seca de soja foi superior à das plantas daninhas, quando cultivada sem restrição de água. Entretanto, em condições restritivas, a massa seca da cultura foi reduzida em todos os experimentos, principalmente no experimento comparativo com $\boldsymbol{D}$. ciliaris. O efeito da restrição de água também foi significativo na redução da fotossintese das plantas na maioria dos experimentos, diminuindo a duração de área foliar e a eficiência de uso da

1 Recebido para publicação em 10.7.2012 e aprovado em 24.10.2013.

2 EMBRAPA - Teresina-PI, Brasil, <rafael.vivian@embrapa.br>; ${ }^{3}$ ESALQ/USP, Piracicaba-SP, BR, ${ }^{4}$ UFV Viçosa-MG, Brasil; ${ }^{5}$ UC-Davis, Davis-CA, USA. 
água. A análise conjunta das variáveis revela maior tolerância das plantas daninhas à deficiência hídrica temporária em relação à soja e com alterações distintas das suas interações e seus mecanismos de competição, em cada experimento.

Palavras-chave: Glycine max, competição por água, Alternanthera tenella, Tridax procumbens, Digitaria ciliaris.

\section{INTRODUCTION}

Plant competition for resources (water, light and nutrients) is frequently reported as the direct cause in crop yield reduction, though it presents distinct effects among species. For example, in soybean and weed interaction, light is the main competitive factor (Pike et al., 1990; King \& Purcell, 1997). However, other factors, such as water and nutrients, are related to the definition of competitive capacity, which may change according to the species, its plasticity and environmental conditions during its growth.

Drought stress effect on soybean yield is also constantly linked to the period of its occurrence during the crop cycle. It is known that low-water availability in the growing season has no much effect on productivity of most species (Costa et al., 1999), with the largest dry matter accumulation between the beginning of flowering and filled grain. However, when there are weeds, which is common at the beginning of crop establishment, the correlation between water demand and ability to tolerate water stress can be changed. In this condition, it is assumed that the drought stress effect should be proportional to the competitive potential of species on absorption and water use efficiency.

Some studies have shown that certain weeds might be more competitive than crop plants under water stress. Desmodium tortuosum, for example, shows greater competitive effect with soybean under lowwater availability than under adequate water supply (Griffin et al., 1989). Other weed species may present equal or less ability of competing when compared to cultivated plants. Coble et al. (1981) found that Ambrosia artemisiifolia's critical period control in drought years was lower than in years with normal rainfall, indicating greater weed aggressiveness in normal water supply.

However, few results accurately define the competition between species, making it difficult to isolate the factors during the competition, especially the effects of water stress, which can interfere on growth and photosynthetic rates (Flexas et al., 2004), in cell signalization and, according to Bray (2002), in plant gene expression.

Considering the substantial impact of three weed species (Alternanthera tenella, Tridax procumbens and Digitaria ciliaris) on Brazilian soybean crops in the Southeast and Central-West regions, this research aims to assess the competitive adjustment of each species and soybean under water stress conditions.

\section{MATERIALS AND METHODS}

Three experiments were conducted individually: soybean + Alternanthera tenella; soybean + Tridax procumbens; and soybean + Digitaria ciliaris in a growth chamber, with controlled conditions of temperature, relative humidity and photosynthetic active radiation (PAR). The minimum and maximum temperatures ranged between $18{ }^{\circ} \mathrm{C}$ and $30{ }^{\circ} \mathrm{C}$, respectively. The daylight was standardized to 14 hours and night-time to 10 hours, with approximately $800 \mu \mathrm{mol}$ photons $\mathrm{m}^{-2} \mathrm{~s}^{-1}$ PAR (20 $\mathrm{cm}$ from light source). Relative humidity remained between $50 \%$ and $80 \%$, according to the minimum and maximum limits at noon $(12 \mathrm{pm})$ and in the early morning $(6 \mathrm{am})$, respectively.

For each experiment, cylindrical pots with $4 \mathrm{~L}$ were used $(15 \mathrm{~cm}$ diameter by $30 \mathrm{~cm}$ height and approximately $140 \mathrm{~g}$ ), filled with RedYellow soil, which was sieved and remained incubated for acidity correction (approximately $\mathrm{pH}$ 6.0) at the end of the period. Total mass 
per pot (pot + dry soil + water + seed) was measured in the beginning in order to set the subsequent water content corrections. We used $900 \mathrm{ml}$ of water in each pot to reach the water saturation content in the soil (previously calculated values).

Irrigation control was performed daily by weighing individual pots, being considered as a basis for water content replacement, according to evapotranspired water in each pot. In order to establish drought stress, drawn pots were not irrigated until reaching $50 \%$ of the water mass initially added, corresponding to $450 \mathrm{~mL}$ of water per pot. Afterwards, water control from pots with water stress conditions was conducted based on daily evapotranspiration. The reduction of water content started 20 days after transplanting (DAT), being kept up to 40 DAT. Thereafter, all pots were supplied with water. According to the water retention curve, the soil remained with about $1500 \mathrm{Kpa}$ of matric potential during water stress period.

Soybean seeds ('BRS 232' semi-early cycle) and weeds were pre-germinated in phenolic foam and immediately transferred to the pots ensuring uniformity on establishing seedlings. Plants were irrigated with nutrient solution previously calculated in order to adequately supply soybean nutrition. All weeds received the same nutrient solution and its electrical conductivity changed from $0.9 \mathrm{~ms} \mathrm{~cm}^{-1}$ at 15 DAT to $1.2 \mathrm{~ms} \mathrm{~cm}^{-1}$, remaining until the end of experiments.

Each experiment was arranged in a complete randomized design, using three levels for the plant composition factor (soybean monoculture, soybean + weed competition and weed monoculture) and two levels for the water stress factor (no water stress and water stress), considering a factorial arrangement $(3 \times 2)$. Total density per pot was established as two plants, either alone or in competition $(50 \%$ of each species), using a replacement series for determining the competitive interaction. A total of 60 pots per experiment were used 10 pots per treatment. Three replicates were used as destructive samples, including leaf area (LA) and total dry matter of each plant at 50 DAT (soybean flowering), 70 DAT and at the end of experiments, as well as total dry matter per pot (TDM). LA values were used to measure leaf area duration (LAD), which is considered essential in dry matter production mostly when kept in competition. It is known that a great LAD allows more light interception and, consequently, greater input on carbon assimilation. Non-destructive evaluations were also made from net photosynthesis (A) and plant transpiration (TR) analyses at 35 and 50 DAT using four replicates per treatment. The water use efficiency estimate ( $\mu \mathrm{mol} \mathrm{CO} \mathrm{CO}_{2} \cdot \mathrm{mmol}^{-1} \mathrm{H}_{2} \mathrm{O}$ ) was obtained by the $\mathrm{A}$ and TR ratio of each plant, at 35 DAT.

All data, along with plant evapotranspiration demands, were used to interpret the results. Coefficients kcw and kwc (on combination) were also estimated, which represent, respectively, the competition coefficient of species $a$ (soybean) in relation to species $b$ (weed) and the competition of $b$ in relation to $a$, by means of equations (1) and (2) proposed by De Wit (1960):

$$
\begin{aligned}
& k c w=\frac{(1-P a)}{(D M c c / D M c m)-P c} \quad(0<\mathrm{Pc}<1) \\
& k w c=\frac{(\text { eq. } 1)}{(D M w c / D M w m)-P d} \quad(0<\mathrm{Pd}<1)
\end{aligned}
$$

where $P a$ is the proportion of plant species $a$ and $P b$ is the proportion of plant species $b$, both in competition. DMcc and DMcm correspond to the dry matter per plant of soybean in competition $(c)$ and in monoculture $(m)$, as well as $D M w c$ and $D M w m$ represent the dry matter per plant of weed, in competition and in monoculture, respectively. It is assumed that $k c w$ and $k w c$ coefficients do not change according to proportional variation between species $a$ and $b$, as stated by De Wit (1960), assuming $P c=P d=0,5$.

From these indexes, it was possible to calculate the averages of the relative yield of crop (RYc) and of every weed (RYw), following equations (3) and (4), also proposed by De Wit (1960):

$$
R Y c=\frac{k c w^{*} P a}{k c w+P b}
$$




$$
R Y w=\frac{k w c^{*} P b}{k w c+P a}
$$

Relative yield total $(R Y T)$ was calculated according to the sum of indexes $R Y c$ and $R Y w$, obtained at the end of each experiment.

Net photosynthesis evaluations were carried out with the portable equipment Infrared Gas Analyzer (IRGA), LI-6400 (LI-COR) in fully expanded leaves. Leaves were sampled into three extracts (high, medium and low height level), and each plant was evaluated with one leaf per extract. The averages of each trial represent net photosynthesis of each plant. On the other hand, it was impossible to split the weeds' leaves into extracts, mainly $A$. tenella and $D$. ciliaris, therefore we adopted the average of leaves exposed on the top of the plant. All measurements were carried out from 9 am to $11 \mathrm{am}$, with outlight source set to $800 \mu \mathrm{mol}$ photons $\mathrm{m}^{-2} \mathrm{~s}^{-1}$, regarding equipment variation coefficient $\left(\Delta \mathrm{CO}_{2}+\Delta \mathrm{H}_{2} \mathrm{O}\right)$ less than $1 \%$.

TDM, DMcc and DMwc data were submitted to variance analysis and, when significant, comparisons of means were carried out by using Tukey's test at 5\% probability. The t test was used to verify differences on RYT, RYc, RYw, $\mathrm{kcw}$ and kwc indexes, as well as other comparisons between no stress and brief water stress. The null hypothesis tested was that in which averages of each index obtained between the two water availability conditions were equivalent $[\mathrm{Ho}=(\mu 1-\mu 2)=0]$.

\section{RESULTS AND DISCUSSION}

The analysis of variables TDM, DMc and $\mathrm{DMw}$ show competitive differences for each weed species and soybean grown (Table 1). Mainly for DMw, there were no water stress effects observed on the dry matter, which shows little or no change in the growth of weeds assessed by the reduction of water in the soil. No effect was further noticed on DMw by composition plant (CP) and water stress (WS) interactions. However, significant interactions (CP x WS) were settled to DMc measurements on soybean $\mathrm{x} A$. tenella, $T$. procumbens and $D$. ciliaris trials, indicating that water was restrictive to soybean growth. Moreover, TDM analysis showed an interaction effect of $\mathrm{CP}$ and WS only on the soybean and D. ciliaris trial, which highlights high competition of this weed under low available water content.

Effect between intraspecific and interspecific competition species is better understood from TDM and DMc data (Table 2). Higher TDM values (g per pot) were verified in soybean than in A. Tenella and T. Procumbens, which can be justified by low initial growth and height of these weeds. Usually, initial growth rate is correlated with seed size and reserves, being among the key factors that allow for the

Table 1 - Summary of variance analysis for each experiment (soybean: A. tenella; soybean: T. procumbens and soybean: D. ciliaris) and their dry matter variables (90 days after transplanting)

\begin{tabular}{|c|c|c|c|c|}
\hline \multirow[b]{2}{*}{ Variables } & \multirow[b]{2}{*}{ Sources of variation } & \multicolumn{3}{|c|}{$\mathrm{F}$} \\
\hline & & $\begin{array}{l}\text { Soybean : } \\
\text { A. tenella }\end{array}$ & $\begin{array}{c}\text { Soybean : } \\
\text { T. procumbens }\end{array}$ & $\begin{array}{l}\text { Soybean: } \\
\text { D. ciliaris }\end{array}$ \\
\hline \multirow{3}{*}{ Total dry matter } & Plant composition (PC) & $5.28 * *$ & $24.07 * * *$ & $88.04 * * *$ \\
\hline & Water stress (WS) & $1.84 \mathrm{~ns}$ & $2.83 \mathrm{~ns}$ & $58.95 * * *$ \\
\hline & PC x WS & $0.78 \mathrm{~ns}$ & $0.51 \mathrm{~ns}$ & $76.17 * * *$ \\
\hline \multirow{3}{*}{ Soybean dry matter } & Plant composition (PC) & $259.85 * * *$ & $71.66 * * *$ & $18.55 * *$ \\
\hline & Water stress (WS) & $34.27 * * *$ & $7.76 * *$ & $105.02 * * *$ \\
\hline & PC $x$ WS & $7.56^{* *}$ & $3.49 *$ & $152.49 * * *$ \\
\hline \multirow{3}{*}{ Weed dry matter } & Plant composition (PC) & $27.97 * *$ & $55.03 * * *$ & $113.34 * * *$ \\
\hline & Water stress (WS) & $0.41 \mathrm{~ns}$ & $0.43 \mathrm{~ns}$ & $1.88 \mathrm{~ns}$ \\
\hline & $\mathrm{PC} \times \mathrm{WS}$ & $0.17 \mathrm{~ns}$ & $1.10 \mathrm{~ns}$ & $0.50 \mathrm{~ns}$ \\
\hline
\end{tabular}

Total dry matter - g per pot (pots: $\pm 140 \mathrm{~g}(\mathrm{w})$ and $40 \mathrm{~cm}^{3}(\mathrm{v})$ ); soybean dry matter - g per plant; weed dry matter - g per plant; PC: $100 \%$ soybean, $50 \%$ soybean $+50 \%$ weed and $100 \%$ weed. WS: water stress from the $20^{\text {th }}$ to the 40 th day after transplanting. ns - no significance; * $(\mathrm{P}<0.1)$;** $(\mathrm{P}<0,05) * * *(\mathrm{P}<0,01)$. 
Table 2 - Total dry matter (TDM) per pot and soybean dry matter (DMc) per plant obtained in a growth chamber at the end of the competition (90 days after transplanting), for each weed species (W)

\begin{tabular}{|c|c|c|c|c|c|}
\hline \multirow{2}{*}{$\begin{array}{l}\text { Water } \\
\text { supply }\end{array}$} & \multicolumn{5}{|c|}{ Soybean - Alternanthera tenella } \\
\hline & Soybean & Soybean $+\mathrm{W}$ & $\mathrm{W}$ & Soybean & Soybean $+\mathrm{W}$ \\
\hline & \multicolumn{3}{|c|}{ Total Dry Matter (g per pot) } & \multicolumn{2}{|c|}{ Soybean Dry Matter (g per plant) } \\
\hline NW & \multirow{2}{*}{$61.65(4.10) \mathrm{a}$} & \multirow{2}{*}{$60.31(4.35) \mathrm{a}$} & \multirow{2}{*}{$51.58(7.98) b$} & $32.36(0.80) \mathrm{b}$ & $50.98(1.69) \mathrm{a}^{*}$ \\
\hline WS & & & & $29.29(1.68) b$ & $42.49(2.31) \mathrm{a}$ \\
\hline & \multicolumn{5}{|c|}{ Soybean - Tridax procumbens } \\
\hline NW & \multirow{2}{*}{$35.08(2.38) \mathrm{a}$} & \multirow{2}{*}{$32.62(3.28) \mathrm{a}$} & \multirow{2}{*}{$23.44(3.32) b$} & $17.92(1.51) \mathrm{b}$ & $30.17(3.51) \mathrm{a}^{*}$ \\
\hline \multirow[t]{2}{*}{ WS } & & & & $17.16(0.61) b$ & $24.57(1.55) \mathrm{a}$ \\
\hline & \multicolumn{5}{|c|}{ Soybean - Digitaria ciliaris } \\
\hline NW & $72.58(1.11) \mathrm{a}$ & $71.44(2.97) \mathrm{a}^{*}$ & $76.16(3.11) \mathrm{a}$ & $36.29(0.55) b$ & $51.85(3.23) \mathrm{a}^{*}$ \\
\hline WS & $74.99(1.13) \mathrm{a}$ & $45.09(1.17) \mathrm{b}$ & $72.51(2.88) \mathrm{a}$ & $37.49(0.56) \mathrm{a}$ & $29.14(0.95) b$ \\
\hline
\end{tabular}

Values followed by the same letters in the same rows are not significantly different by Tukey’s test $(\mathrm{P}>0,05)$; ${ }^{*}$ Significant difference by $\boldsymbol{t}$ test in column $(\mathrm{P}<0,05)$ of each experiment. Values limited by parentheses represent standard deviation from averages. NW: no water stress; WS: water stress from the 20th to the $40^{\text {th }}$ day after transplanting. Pots: $+140 \mathrm{~g}(\mathrm{w})$ and $40 \mathrm{~cm}^{3}$ (v).

competitive advantages of species (Nisensohn et al., 2011). However, high TDM values of the D. ciliaris monoculture indicate an expressive competitive capacity of this weed with soybean, making their competition very common in soybean crop fields (López Ovejero et al., 2007).

In exception to other species, a significant WS effect $(\mathrm{P}<0,05)$ was observed on soybean and $D$. ciliaris for the TDM variable, reducing it more than 36\% (Table 2). The effect is probably related to the allelophatic action of $D$. ciliaris on soybean, raising allelochemical concentration on soil solution under water restriction. The allelophatic interference of $D$. ciliaris was described initially by Dayaday $\&$ Pons (1978), whose demonstrated allelophatic effects of $D$. ciliaris on maize.

According to DMc values of soybean in monoculture, it was verified that growth restriction is not related to WS, but to other factors, such as light and/or nutrients, without WS effect $(\mathrm{P}>0,05)$ on soybean DMc (Table 2$)$. However, a positive effect $(\mathrm{P}<0,05)$ of WS over $\mathrm{DMc}$ was found in soybean in competition, for all weed experiments. Higher DMc values found in soybean in competition with weed rather than in monoculture normally occur when intraspecific competition is superior to interspecific competition (Table 2). Due to lower soybean competition with weeds, the crop took advantage of resources (light, nutrients) and, therefore, water limitation was explicit at evaluation among treatments with and without WS.

Besides, adaptation to water deficit also diverges among species, according to Inamullah \& Isoda (2005). In a comparative trial between soybean and cotton, we verified decreases in the stomatic area of cotton submitted to water stress. However, under the same conditions, soybean demonstrated reduction only in stomatic density, without interference on stomatic area. The study also exposed that soybean could adapt to lower water contents, due to its reduction on transpiration rate, which revealed less stomatic conductance. Cotton, on the other hand, sustained its transpiration rate due to its high sap flow.

From dry matter analysis, the WS effect and the weed-soybean interactions were correlated with net photosynthesis obtained in each experiment. Firstly, there was no effect of WS on soybean as well as on A. tenella, although we found a net photosynthesis reduction on weeds when growing under competition with soybean (Figure 1). These results highlight again a further intraspecific soybean competition, indicating more competitive capacity for resources between the same species.

The absence of WS effect on the net photosynthesis of soybean and its divergence 

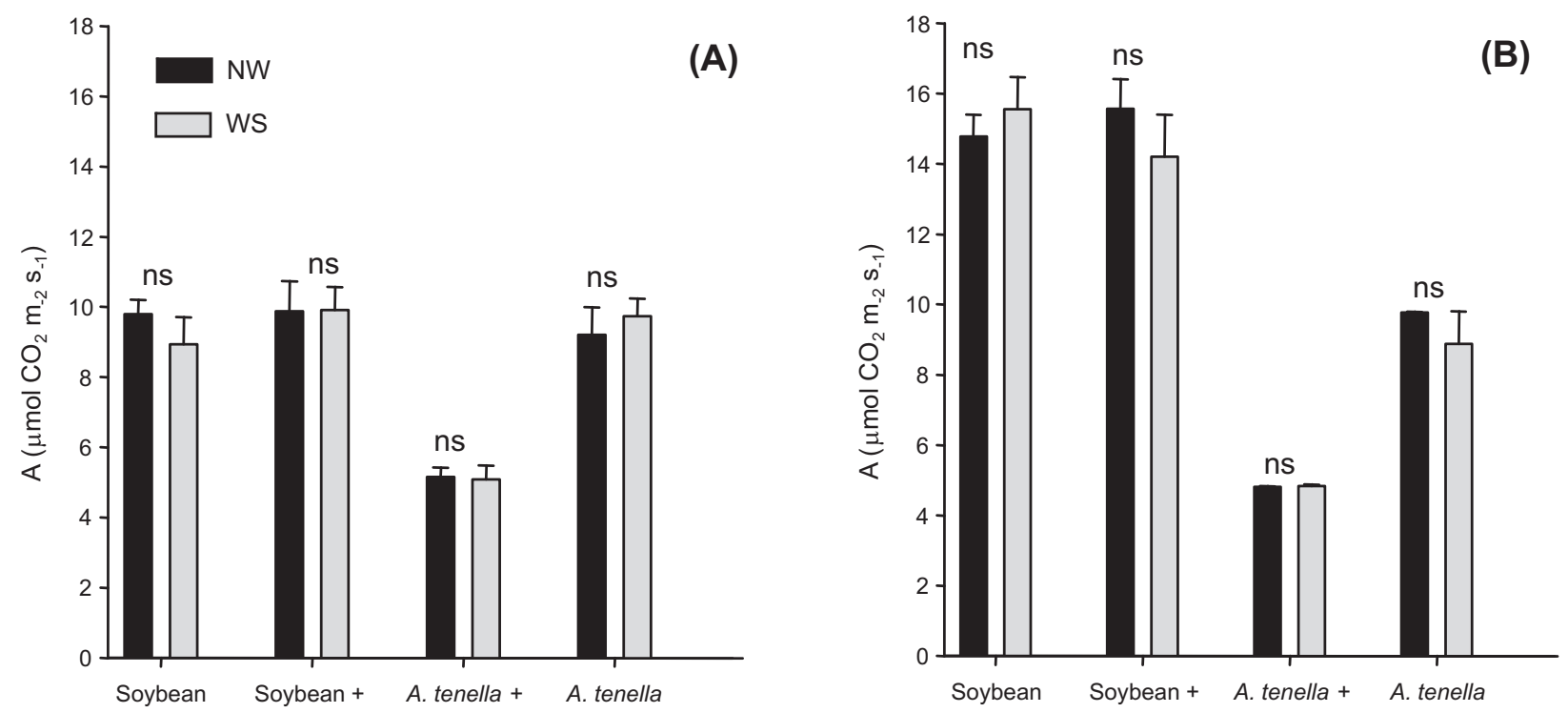

(A)-35 days after transplanting (DAT), (B)-50 DAT. WS - from 20 to 40 DAT. ns - no significant difference between treatments NW and WS by $\boldsymbol{t}$ test $(\mathrm{P}>0,05)$.

Figure 1 - Net photosynthesis estimates $\left(\mathrm{A}-\mu \mathrm{mol} \mathrm{CO}_{2} \mathrm{~m}^{2} \mathrm{~s}^{-1}\right)$ from soybean and Alternanthera tenella in a growth chamber, in monoculture or in competition (+) under normal (NW) or water stress conditions (WS).

with DMc values show how complex the influence of this effect on the outcome regulation is, involving other factors, such as the maintenance of leaf area, the increasing of resource efficiency use or even the ability to regulate the photosynthetic system by other feedbacks. However, it comes out that WS also did not reduce net photosynthesis in weed monoculture (Figure 1). This might happen because of the complexity of WS daily control, although the reduction in net photosynthesis by WS effects was expected. Moreover, slight or no plant effects might be found depending on WS severity, duration and period. According to Inamullah \& Isoda (2005), soybean might be adapted to WS or excessive radiation by changing the leaf position (phototropism), reducing light radiation incidence, sap flow, stomatal conductance and evapotranspiration as a result. Furthermore, they did found considerable effect on net photosynthesis by reduction of $50 \%$ on evapotranspired water. On the other hand, they demonstrated reductions in stomatal conductance, transpiration ratio and in soybean leaf area.

Despite similar net photosynthesis rates with or without water stress, the dry matter per plant of soybean and $A$. tenella were lower in the end of the experiment for the drought treatments. This result might be related to other energy costs resulting in maintenance of net photosynthesis rates. Some changes in leaf ontogeny, for example, allowed distinction in the energy requirements of plants, according to phenological stages and environmental conditions. In addition, cell elongation is more severely affected by water stress in relation to the potential of carbon assimilation, being known that sink-source relations are customized under WS as a result of plant reallocation resources (McCoy et al., 1990). In some cases, distribution of resources by individual source-leaf are reduced, allowing a greater accumulation in storage leaves.

However, a significant $(\mathrm{P}<0,05)$ effect of water stress was observed in $T$. procumbens (Figure 2) and D. ciliaris net photosynthesis experiments (Figure 3). There was a decrease in soybean net photosynthesis, in monoculture or even in competition with T. procumbens. Nevertheless, the net photosynthesis of the weed was reduced only in monoculture without consequences under soybean competition. After stress 
(drought treatments), net photosynthesis rates increased again, although they were not the same observed in plants not submitted to water deficit. These data confirm
DMc reduction under WS as well as a lower DMc in monoculture than in competition with $T$. procumbens. Similar to the A. tenella experiment, soybean intraspecific
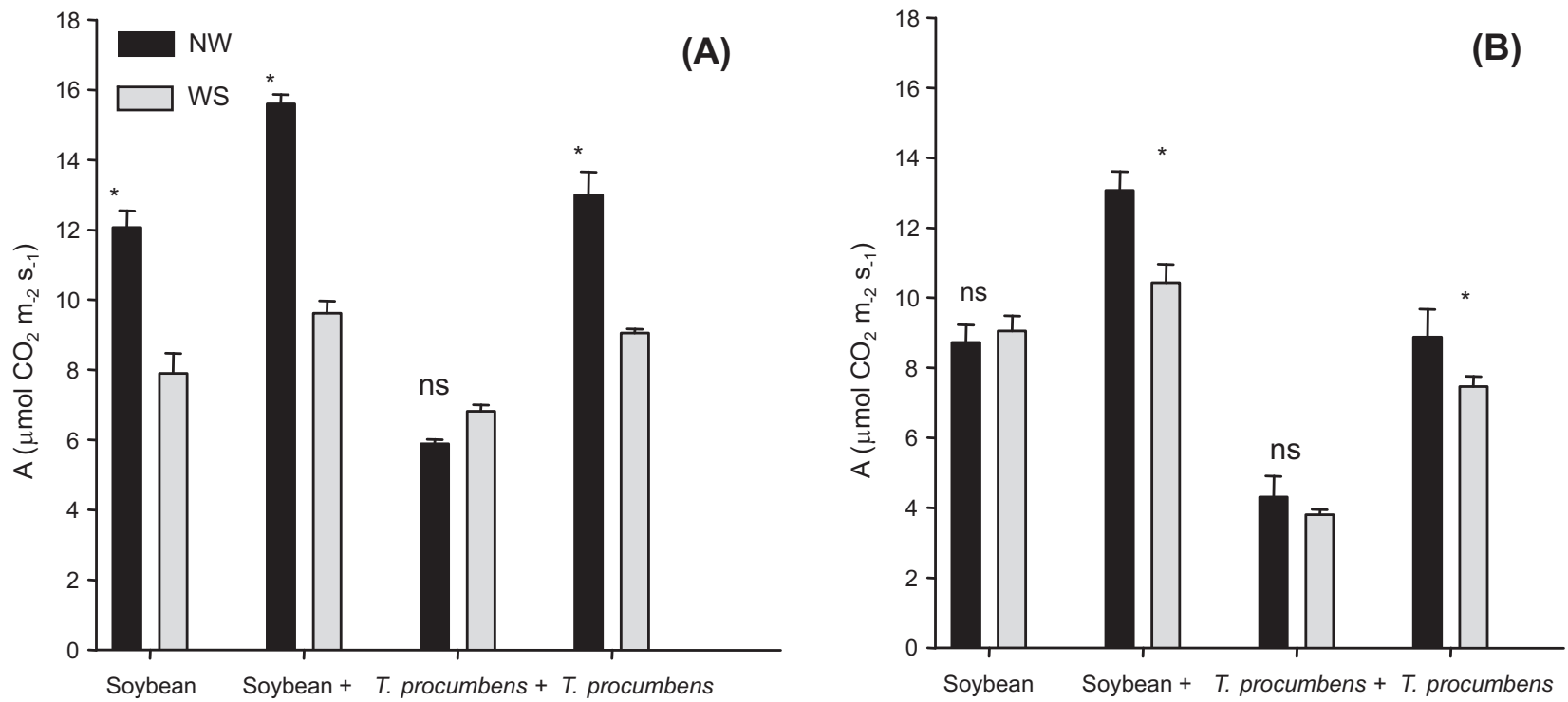

(A)-35 days after transplanting (DAT), (B)-50 DAT. WS - from 20 to 40 DAT. ns - no significant * Significant difference between treatments NW and WS by $\boldsymbol{t}$ test $(\mathrm{P}<0,05)$.

Figure 2 - Net photosynthesis estimates $\left(\mathrm{A}-\mu \mathrm{mol} \mathrm{CO}_{2} \mathrm{~m}^{2} \mathrm{~s}^{-1}\right)$ from soybean and Tridax procumbens into growth chamber, in monoculture or competition (+) under normal (NW) or water stress conditions (WS).
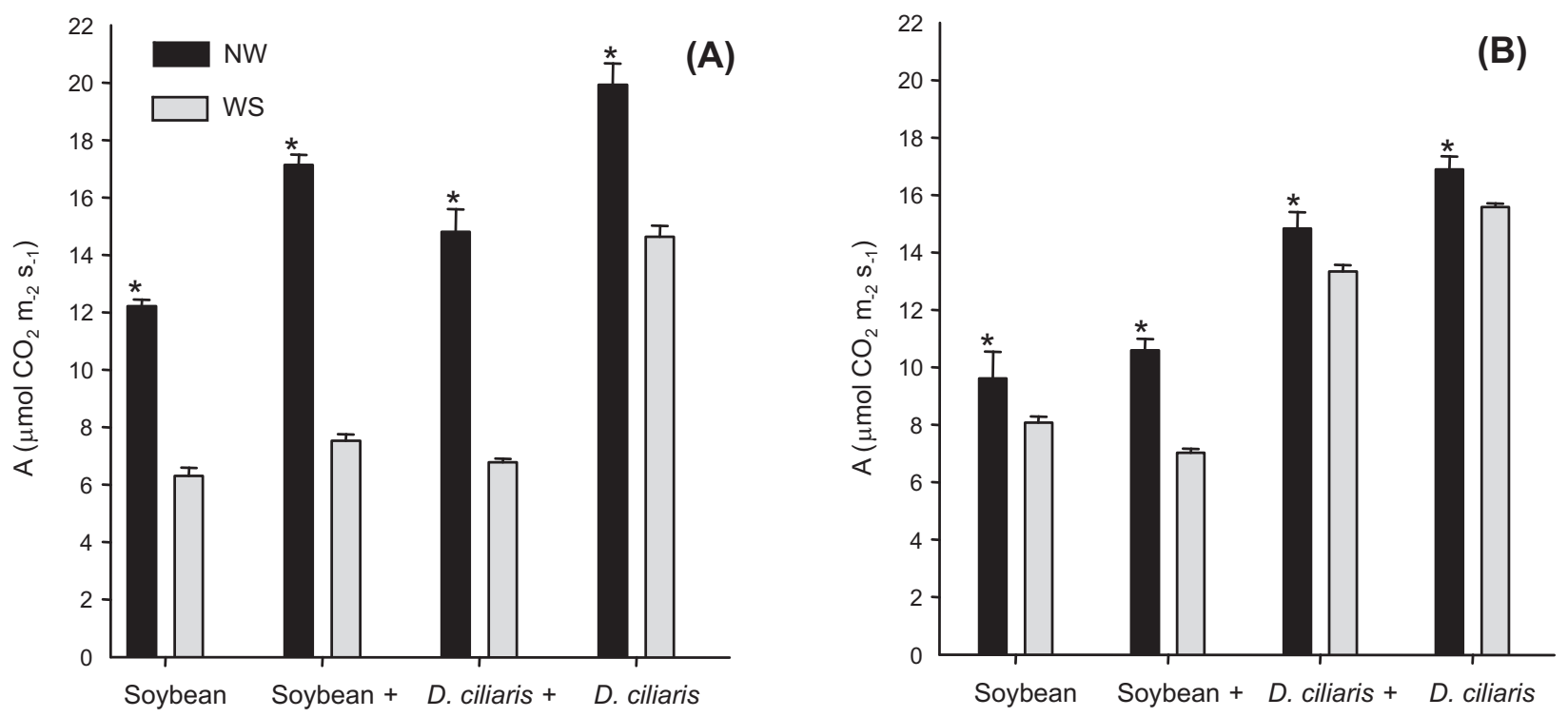

(A)-35 days after transplanting (DAT), (B)-50 DAT. WS - from 20 to 40 DAT. ns - no significant * Significant difference between treatments NW and WS by $\boldsymbol{t}$ test $(\mathrm{P}<0,05)$.

Figure 3 - Net photosynthesis estimates $\left(\mathrm{A}-\mu \mathrm{mol} \mathrm{CO} \mathrm{C}^{2} \mathrm{~s}^{-1}\right)$ from soybean and Digitaria ciliaris in a growth chamber, in monoculture or competition $(+)$ under normal (NW) or water stress conditions (WS). 
competition was higher than interspecific competition (soybean $+T$. procumbens), demonstrating weed advantage under stress conditions.

In the last experiment, net photosynthesis reduction was also verified for both soybean and $D$. ciliaris monoculture under water stress (Figure 3). Unlike the other weed species, $D$. ciliaris and soybean had similar net photosynthesis rates in competition. Water stress was also effective on net photosynthesis reduction for weed and soybean in competition, with partial recovery of photosynthetic potential after stress phase.

Considering the differences of each experiment, leaf area duration (LAD) and water use efficiency (WUE) were estimated at 35 and 50 DAT in order to better demonstrate the drought stress tolerance of weeds, as well as their ability to compete with soybean (Table 3).

Soybean LAD estimated under WS conditions remained constant for most of the experiments in monoculture or even with weed competition. With $A$. tenella and $T$. procumbens competition, soybean LAD was still higher in relation to soybean LAD in monoculture (Table 3), although it was found similar values of LAD for soybean and $D$. ciliaris, highlighting the competitive potential of $D$. ciliaris.

These figures support the remarks made by Costa et al. (1999), who reported no interference in radiation interception of soybean under WS on vegetative stage, without effect on flowering and grain development, including even greater WUE by soybean. Despite cultivar variations, studies carried out in drought conditions show that soybean has high potential on osmotic adjustment and on stomatal conductance reduction allowing the maintenance of its leaf turgor (James et al., 2008).

However, the same WS interfered in the LAD of soybean competition, affecting final DMc, which means that competitive relations with weeds modify the efficiency on crop

Table 3 - Estimates of leaf area duration (LAD) and water use efficiency (WUE) at 35 and 50 days after transplanting (DAT) on Alternanthera tenella, Tridax procumbens and Digitaria ciliaris experiments with soybean in competition $(+)$ or monoculture in a growth chamber

\begin{tabular}{|c|c|c|c|c|c|c|}
\hline \multirow{3}{*}{ Composition } & \multirow{2}{*}{\multicolumn{2}{|c|}{$\begin{array}{c}\text { LAD (days) } \\
50-70 \text { DAT }\end{array}$}} & \multicolumn{4}{|c|}{ WUE $\left(\mu \mathrm{mol} \mathrm{CO} 2 \cdot \mathrm{mmol}^{-1} \mathrm{H}_{2} \mathrm{O}\right)$} \\
\hline & & & \multicolumn{2}{|c|}{35 DAT } & \multicolumn{2}{|c|}{50 DAT } \\
\hline & NW & WS & NW & WS & NW & WS \\
\hline & \multicolumn{6}{|c|}{$($ Soybean - A. tenella $)$} \\
\hline Soybean & \multicolumn{2}{|c|}{$0.73 \mathrm{~b}$} & $2.72 \mathrm{~b}$ & $2.84 \mathrm{~b}$ & \multicolumn{2}{|c|}{$6.49 \mathrm{a}$} \\
\hline Soybean + & \multicolumn{2}{|c|}{$1.07 \mathrm{a}$} & $3.47 \mathrm{a}$ & $3.91 \mathrm{a}^{*}$ & \multicolumn{2}{|c|}{$6.44 \mathrm{a}$} \\
\hline A. tenella + & \multicolumn{2}{|c|}{$0.42 \mathrm{~b}$} & $2.36 \mathrm{~b}$ & $3.21 \mathrm{ab}^{*}$ & \multicolumn{2}{|c|}{$4.18 \mathrm{~b}$} \\
\hline \multirow[t]{2}{*}{ A. tenella } & \multicolumn{2}{|c|}{$0.46 \mathrm{~b}$} & $3.62 \mathrm{a}$ & $3.24 \mathrm{ab}$ & \multicolumn{2}{|c|}{$4.46 \mathrm{ab}$} \\
\hline & \multicolumn{6}{|c|}{ (Soybean - T. procumbens) } \\
\hline Soybean & $0.58 \mathrm{~b}$ & $0.53 \mathrm{~b}$ & $6.68 \mathrm{a}$ & $6.45 \mathrm{a}$ & $5.25 \mathrm{~b}$ & $5.74 \mathrm{a}$ \\
\hline Soybean + & $0.76 \mathrm{a}$ & $0.77 \mathrm{a}$ & $6.70 \mathrm{a}^{* *}$ & $4.62 \mathrm{~b}$ & $6.27 \mathrm{a}^{*}$ & $4.26 \mathrm{~b}$ \\
\hline T. procumbens + & $0.32 \mathrm{c}$ & $0.27 \mathrm{c}$ & $3.61 \mathrm{~b}$ & $4.49 \mathrm{~b}^{* *}$ & $1.12 \mathrm{c}^{*}$ & $0.83 \mathrm{~d}$ \\
\hline \multirow[t]{2}{*}{ T. procumbens } & $0.65 \mathrm{~b}^{*}$ & $0.50 \mathrm{~b}$ & $4.44 \mathrm{~b}$ & $4.47 \mathrm{~b}$ & $1.44 \mathrm{c}$ & $1.34 \mathrm{c}$ \\
\hline & \multicolumn{6}{|c|}{ (Soybean - D. ciliaris) } \\
\hline Soybean & $1.07 \mathrm{ab}^{*}$ & $0.79 \mathrm{~b}$ & $4.46 \mathrm{~d}$ & $4.94 \mathrm{~b}$ & \multicolumn{2}{|c|}{$6.26 \mathrm{a}$} \\
\hline Soybean + & $1.20 \mathrm{ab}^{*}$ & $0.85 \mathrm{~b}$ & $5.78 \mathrm{c}^{*}$ & $5.44 \mathrm{a}$ & \multicolumn{2}{|c|}{$5.25 \mathrm{~b}$} \\
\hline D. ciliaris + & $0.88 \mathrm{~b}^{*}$ & $0.19 \mathrm{c}$ & $7.16 b^{* *}$ & $2.76 \mathrm{c}$ & \multicolumn{2}{|c|}{$2.67 \mathrm{c}$} \\
\hline D. ciliaris & $1.49 \mathrm{a}$ & $1.35 \mathrm{a}$ & $8.19 \mathrm{a}^{* *}$ & $3.04 \mathrm{c}$ & \multicolumn{2}{|c|}{$2.85 \mathrm{c}$} \\
\hline
\end{tabular}

Values followed by the same letters in the same columns of each experiment are not significantly different by Tukey's test (P>0.05);

** Significant difference between NW and WS treatments within the same rows by $\boldsymbol{t}$ test $(\mathrm{P}<0,05) ; *(\mathrm{P}<0,10)$. NW - no water stress; WS

- water stress from 20 to 40 DAT. 
photosynthetic assimilation. Moreover, it was not possible to emphasize the competitiveness on weeds under water stress by using only net photosynthesis rates, since the compensatory effect involving monoculture and competition of soybean with WS is not the same.

Most of weeds also had slighter LAD than soybean under crop competition, except for $D$. ciliaris (Table 3 ). $T$. procumbens LAD, for instance, was reduced from 0,65 to 0,50 days suggesting low tolerance to WS. However, water deficit did not interfere on total dry matter of this species (Table 2), suggesting that other parameters must be included on its assessment.

Observations of soybean WUE indicate that plants in monoculture (35 DAT) sustain their efficiency during water stress, although this can be changed when there is weed competition (Table 3). At 50 DAT, after fertirrigation being restored, the initial water stress effects are no longer shown on soybean in competition with $A$. tenella or $D$. ciliaris, remaining on $T$. procumbens only.

Alternanthera tenella WUE under WS was equal to soybean at 35 DAT, becoming more competitive with the crop, revealing its tolerance in low soil water content. The same can be observed for $T$. procumbens. In contrast, WUE of $D$. ciliaris was sharply reduced under water deficiency, even though the WUE reduction did not change its final dry matter production. In grasses, such as $D$. ciliaris, the water stress can inhibit the photosynthetic capacity, even in $\mathrm{C} 4$ species with greater resistance to $\mathrm{CO}_{2}$ diffusion (Kaiser, 1987), and consequently the WUE. However, its high efficiency during most part of the growth cycle seems to balance the negative effect of water stress in the WUE. Beneath normal water availability, the weed WUE remained high, outpacing culture.

WUE estimates at 50 DAT reveal partial or total recovery of species submitted to drought, excluding the $T$. procumbens experiment, at which soybean and weed showed smaller WUE than others without WS. Despite the same temperature, light and humidity conditions, growth level variations of each weed might interact with soybean physiological responses, especially under water stress.
Dry matter production analysis, relative yield diagrams (RYc and RYw) and relative yield total (RYT) obtained from replacement series give us support on competitive interpretation of each species. In these diagrams (Figures 4 to 9), concave and convex lines indicate correspondingly lesser or higher resource use and capture in relation to other species, while straight lines indicate similar competitiveness.

RYc analysis between soybean and A. tenella (Figure 4) demonstrated competitive advantage of soybean over the weed. Higher soybean development and decrease of A. tenella RYw (g per plant) may be observed by comparison between convex and concave lines in the diagram. This suggests that soybean growth, considering the same emergency period, can reduce as much as possible the growth of $A$. tenella. The same shape in the curve can be observed in plants kept under temporary water stress (Figure 5), although a reduction on divergence between lines can be observed.

RYT, expressed with a dashed line, illustrates that both species have the same competition niche, i.e., have similar resource demands (Figures 4 and 5). This can be considered when the sum of RYc and RYw is not different from 1.0, which can be seen for soybean and $A$. tenella. In cases of higher RYT, the interpretation would be that species compete for different resources. RYT below 1.0 indicates antagonism between species when in competition (De Wit \& Goudriaan, 1978).

Similar results were observed for the second species (Figures 6 and 7). The marked convexity on the RYc curve expresses a high competitive effect of soybean with $T$. procumbens, although this effect is small in terms of water stress. RYT observations also represent competition between soybean and $T$. procumbens for the same resources, independently of drought treatment.

However, comparisons between soybean and $D$. ciliaris diagrams (Figure 8 and 9) were completely different in relation to water availability even with a greater soybean effect in the weed considering the same emergency period and absence of water stress (Figure 8). The results (Figure 9) point up previously 


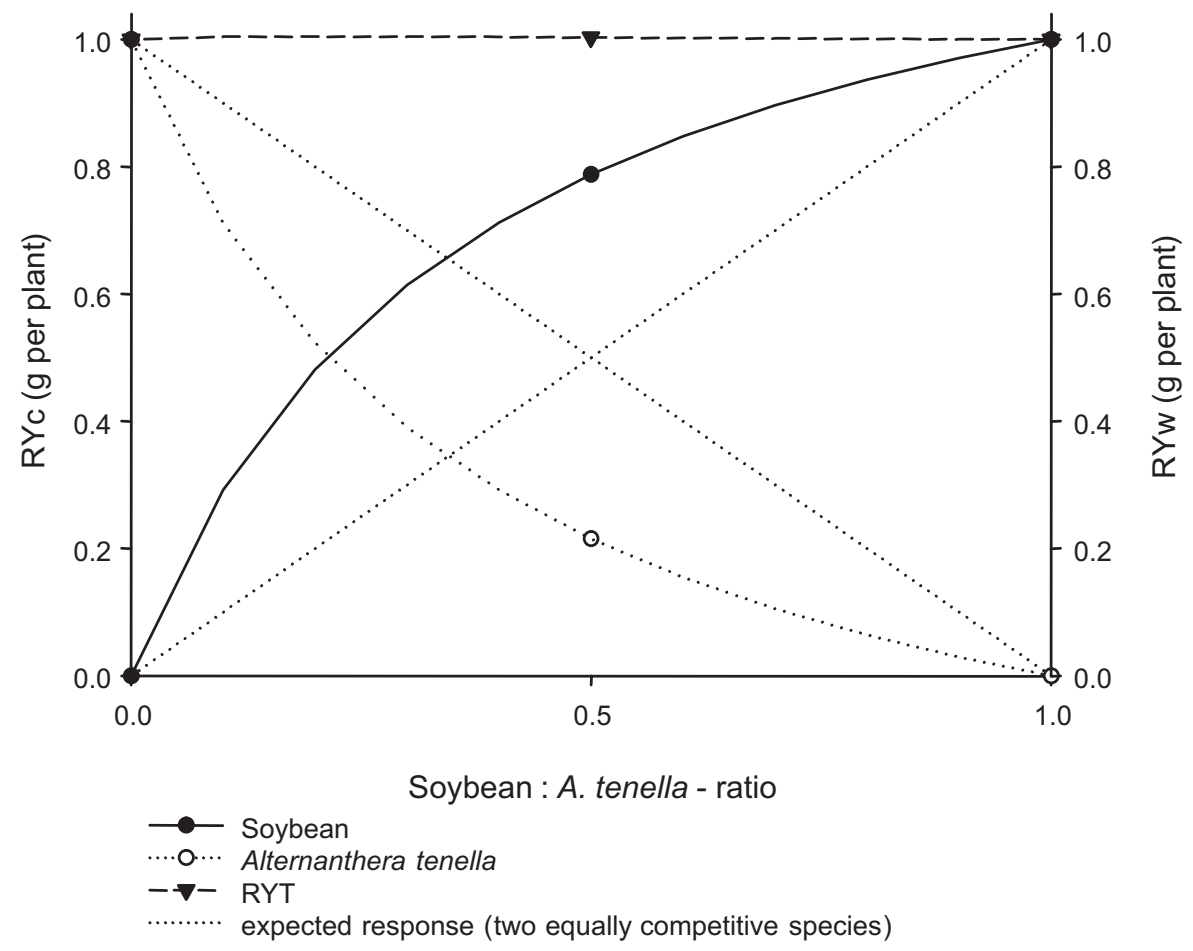

Figure 4 - Relative yields (g dry matter per plant) to crop (RYc) and weed (RYw) as well as relative yield total (RYT) estimated from soybean and Alternanthera tenella grown in monoculture or in competition in a replacement series in a growth chamber.

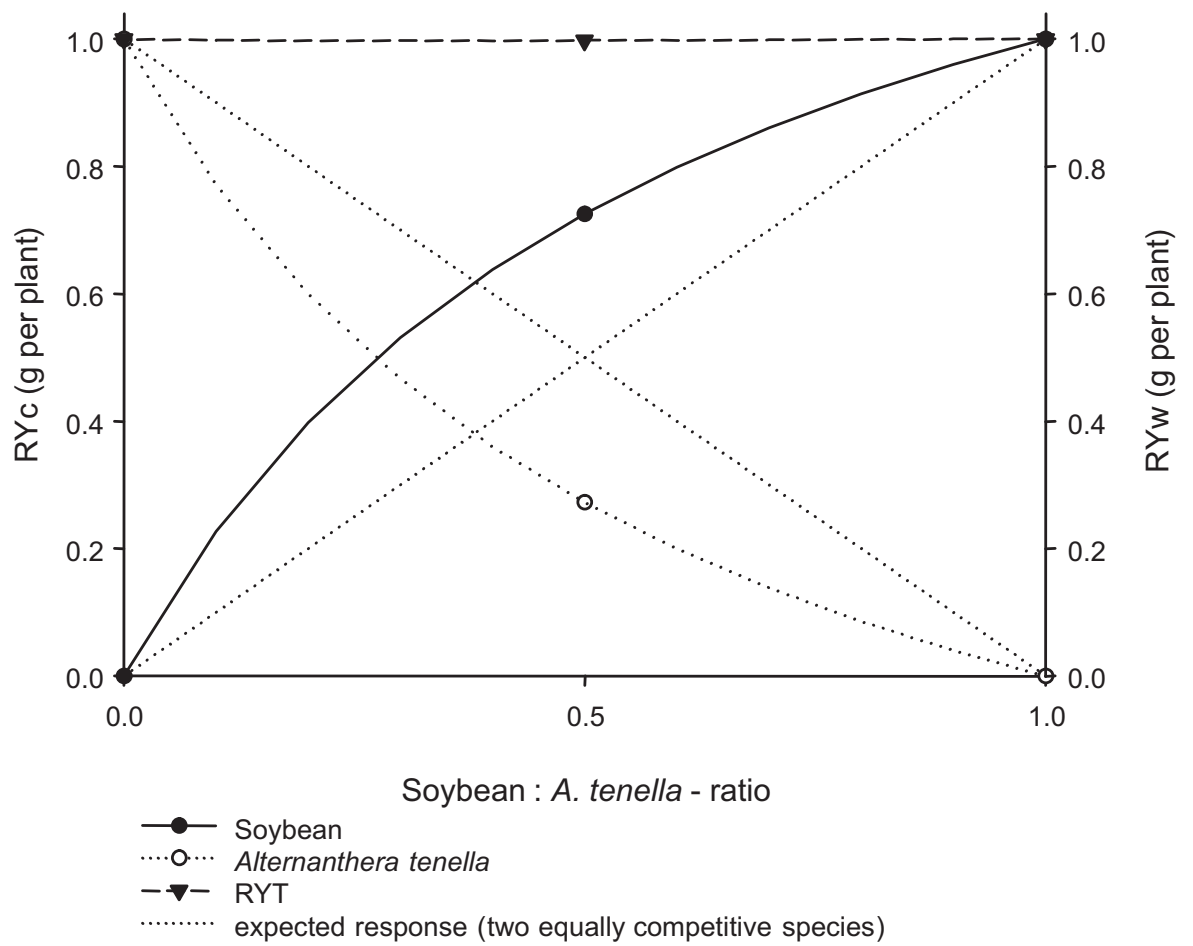

Figure 5 - Relative yields (g dry matter per plant) to crop (RYc) and weed (RYw) as well as relative yield total (RYT) estimated from soybean and Alternanthera tenella grown under water stress, in monoculture or in competition in a replacement series in a growth chamber. 


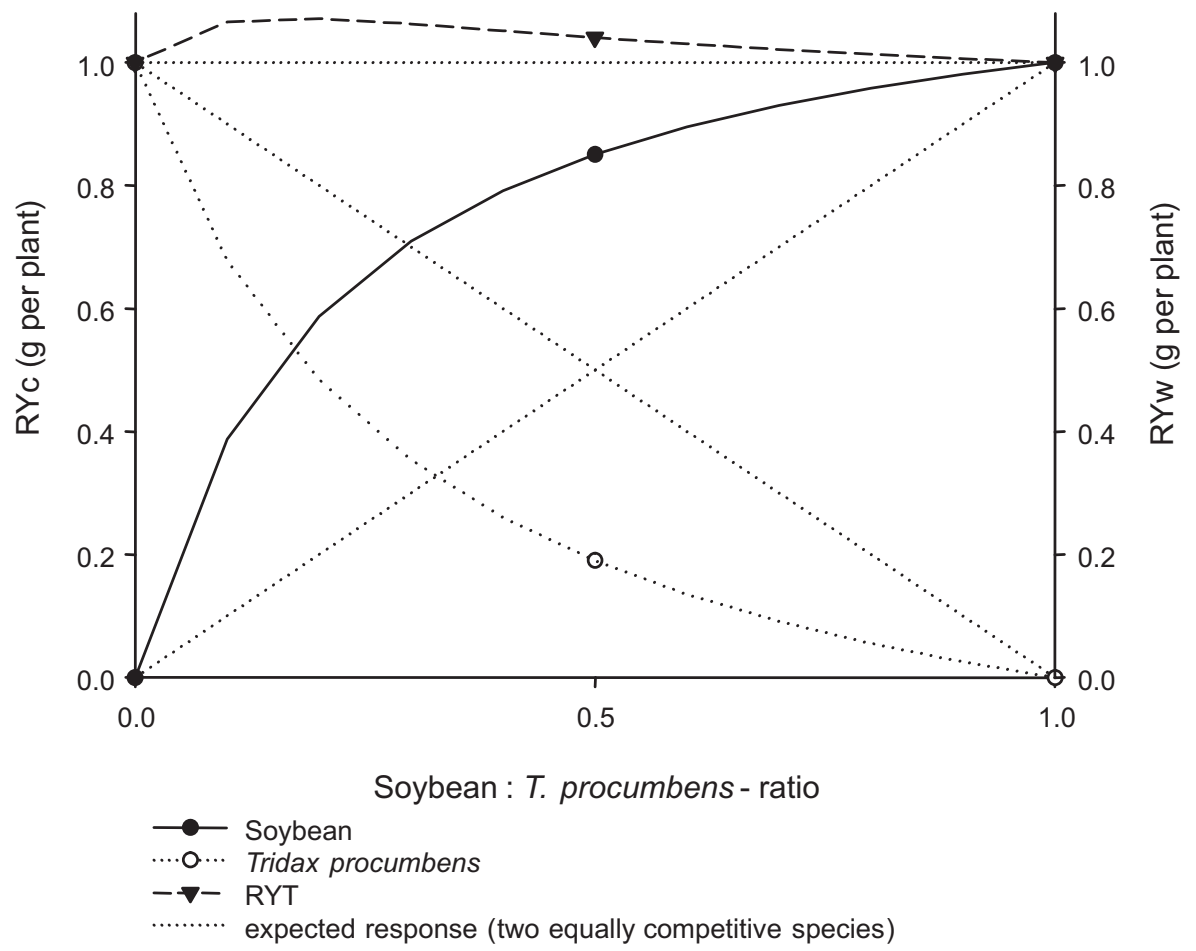

Figure 6 - Relative yields (g dry matter per plant) to crop (RYc) and weed (RYw) as well as relative yield total (RYT) estimated from soybean and Tridax procumbens grown in monoculture or in competition in a replacement series in a growth chamber.

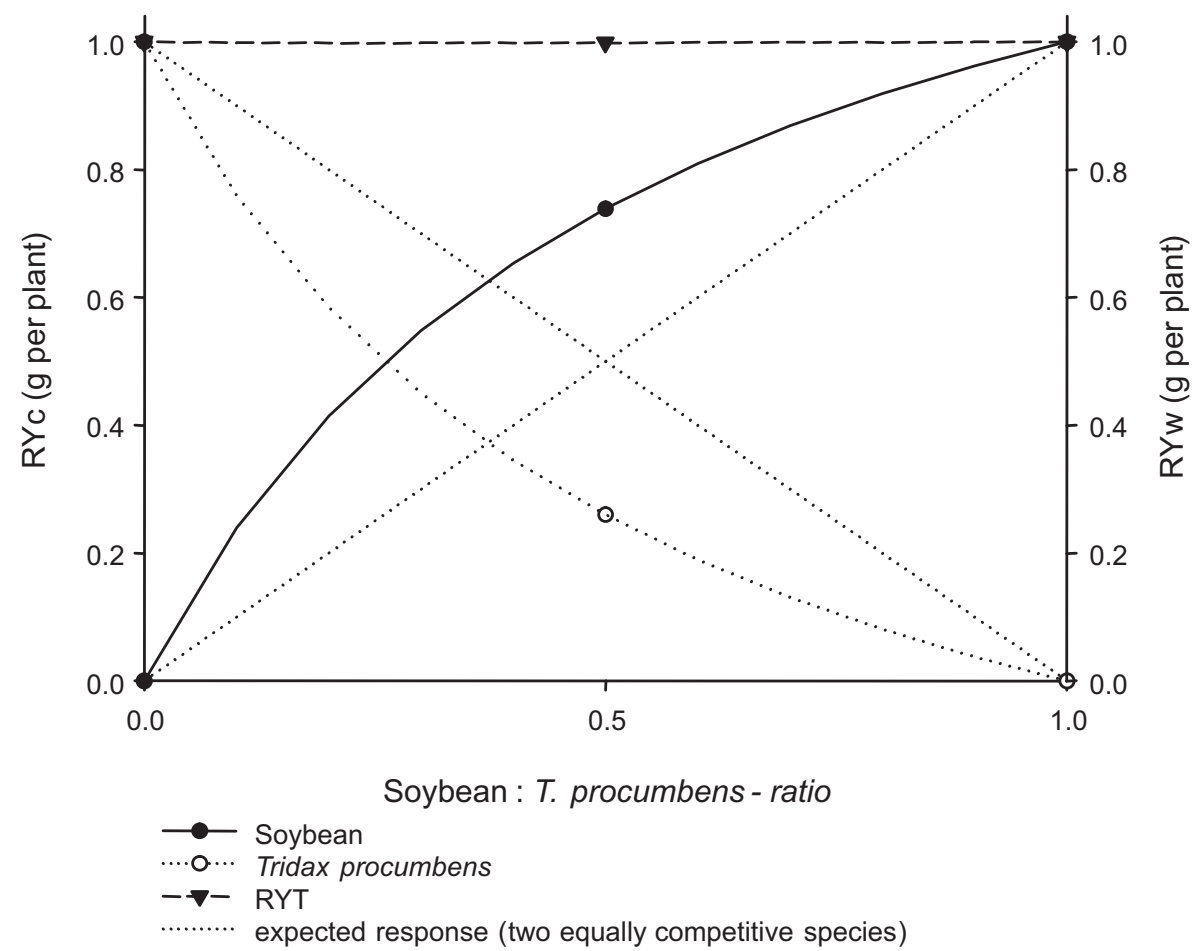

Figure 7 - Relative yields (g dry matter per plant) to crop (RYc) and weed (RYw) as well as relative yield total (RYT) estimated from soybean and Tridax procumbens grown under water stress, in monoculture or in competition in a replacement series in a growth chamber. 
reported interactions between water stress and plant composition. Relative yield of each plant and relative yield total of soybean and $D$. ciliaris in competition were reduced under water stress, as verified by the concavity of the RYc and RYw curves (Figure 9). In addition, RYT was less than 1.0 , i.e., the species showed antagonist competition, what might be suggested by the allelopathic action interference.

Among the findings, Rice (1974) identified three substances exuded by roots of $D$. ciliaris capable of inhibiting nitrogen fixing bacteria and also reducing nitrification process in the soil. Later, Dayaday \& Pons (1978) demonstrated the allelopathic action of $D$. ciliaris on maize growth with interference only by weed radical portion. In terms of field experiments, the allelopathic effects can interact with competition for resources, mainly nitrogen and light, being hard to distinguish them.

In order to confirm the evidences, RYc and $\mathrm{RYw}$ rates and clustering coefficients ( $\mathrm{kcw}$ and kwc) were comparatively analyzed for every experiment (Table 4). Initially, it was verified whether the water stress affects RYw and kwc of both $A$. tenella and $T$. procumbens, as a result of tolerance of these species to short periods of water stress. On the other hand, RYc and $\mathrm{kcw}$ estimated for soybean were lower under water stress in comparison with those obtained without drought conditions. It is noticed that clustering coefficients point out to how much a species interferes in the space of other species. At the same time, it is assumed that these are independent of planting density, when RYT is no different from 1.0.

The comparative analysis of RYT, RYc, $\mathrm{RYw}, \mathrm{kcw}$ and $\mathrm{kwc}$ of the $D$. ciliaris experiment shows the effect of water stress in all calculated indices, as well as the antagonistic interference of $D$. ciliaris on soybean dry matter production (Table 4). Besides, dry matter reduction of crop and weed competition was verified under water stress.

A. tenella showed relative tolerance to water stress, increasing its competitiveness with soybean. This can be emphasized by its leaf area duration, no reduction on final dry matter as well as its water use ability in conditions of water stress. Its tolerance to stress and response plasticity may be linked to high width and wax cuticle as well as its high trichome density, as evidenced by Ferreira et al. (2003). Moreover, this species has intermediary photosynthetic cycle (Gowik et al., 2006), with a high potential of carbon assimilation, with a greater competition still being possible when its germination precedes the crop. Another species in the same gender, Alternanthera philoxeroides, has similarities with A. tenella, being a common weed in tropical and sub-tropical countries. According to Wilson et al. (2007), the fast growth capacity after shoot removal or its tolerance to harsh environments contributes to A. philoxeroides proliferation in agricultural areas.

However, there are no conclusive evidences that $T$. procumbens was tolerant to water stress, although estimated RYw and $\mathrm{kcw}$ were not statistically significant with or without drought condition. The species also showed similarities between estimated WUE under normal or in reduced water availability in monoculture, with increase WUE when grown with soybean. Despite observations of allelopathic consequence on rice (Holm et al., 1997), there was no indication of $T$. procumbens affecting soybean, according to RYT diagrams.

Results from the $D$. ciliaris experiment illustrate high competitive potential of this species with soybean, considering its high dry matter production, huge net photosynthesis and leaf area duration. However, considering the same period of emergency, soybean has maintained its intraspecific dominance rather than interspecific competition, as evidenced by other experiments. Under water stress, the competitive interaction of soybean and D. ciliaris demonstrated great variation on parameters in relation to the monoculture. Unlike established for the crop without water stress, the decrease of water soil content reduced the final dry matter of both soybean and weed. According to the variance analysis (Table 2) and relative yield diagrams (Figures 8 and 9) between soybean and D. ciliaris, these species have a discrepant interaction, with tough indication of allelopathic effects on D. ciliaris.

Considering all variables and the competitive interaction among species, it was 


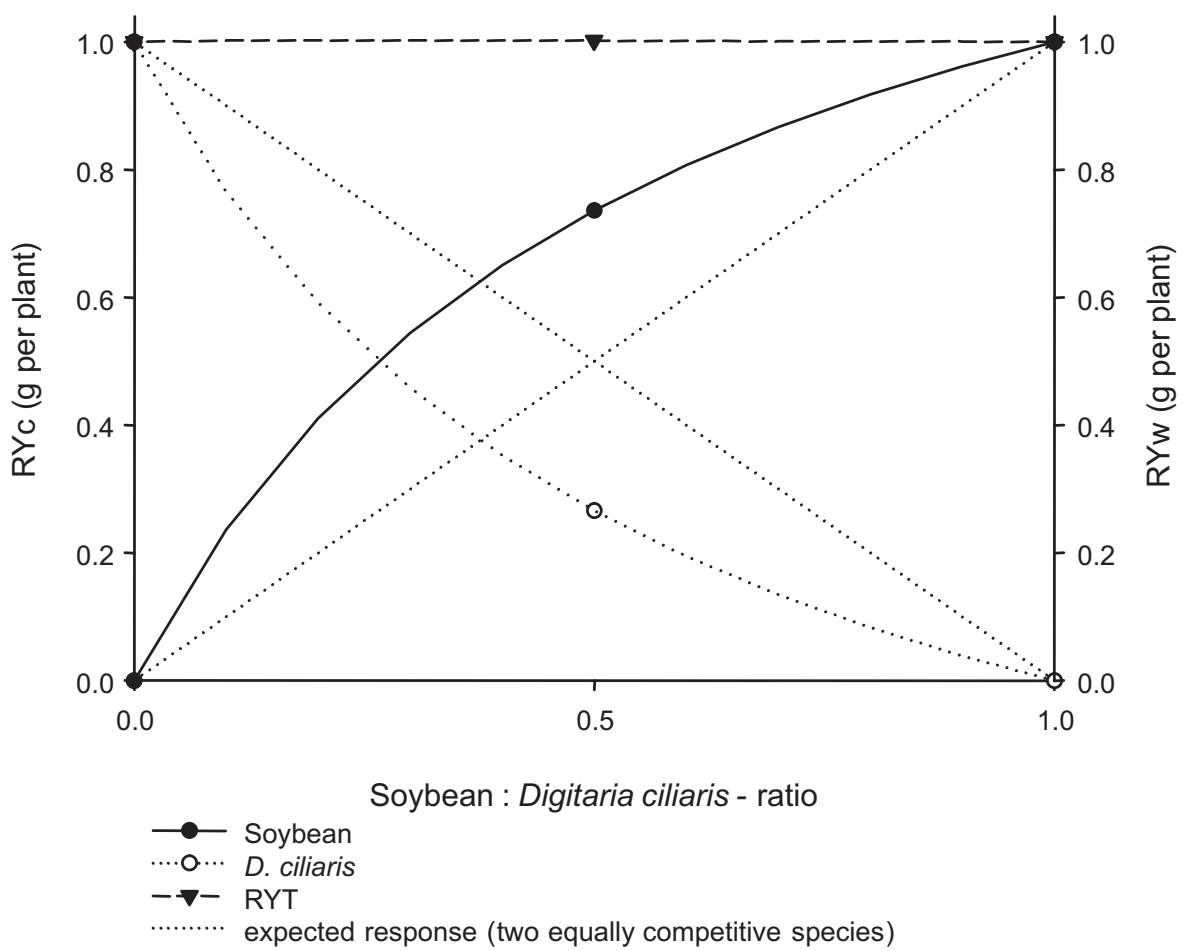

Figure 8 - Relative yields (g dry matter per plant) to crop (RYc) and weed (RYw) as well as relative yield total (RYT) estimated from soybean and Digitaria ciliaris grown in monoculture or in competition in a replacement series in a growth chamber.

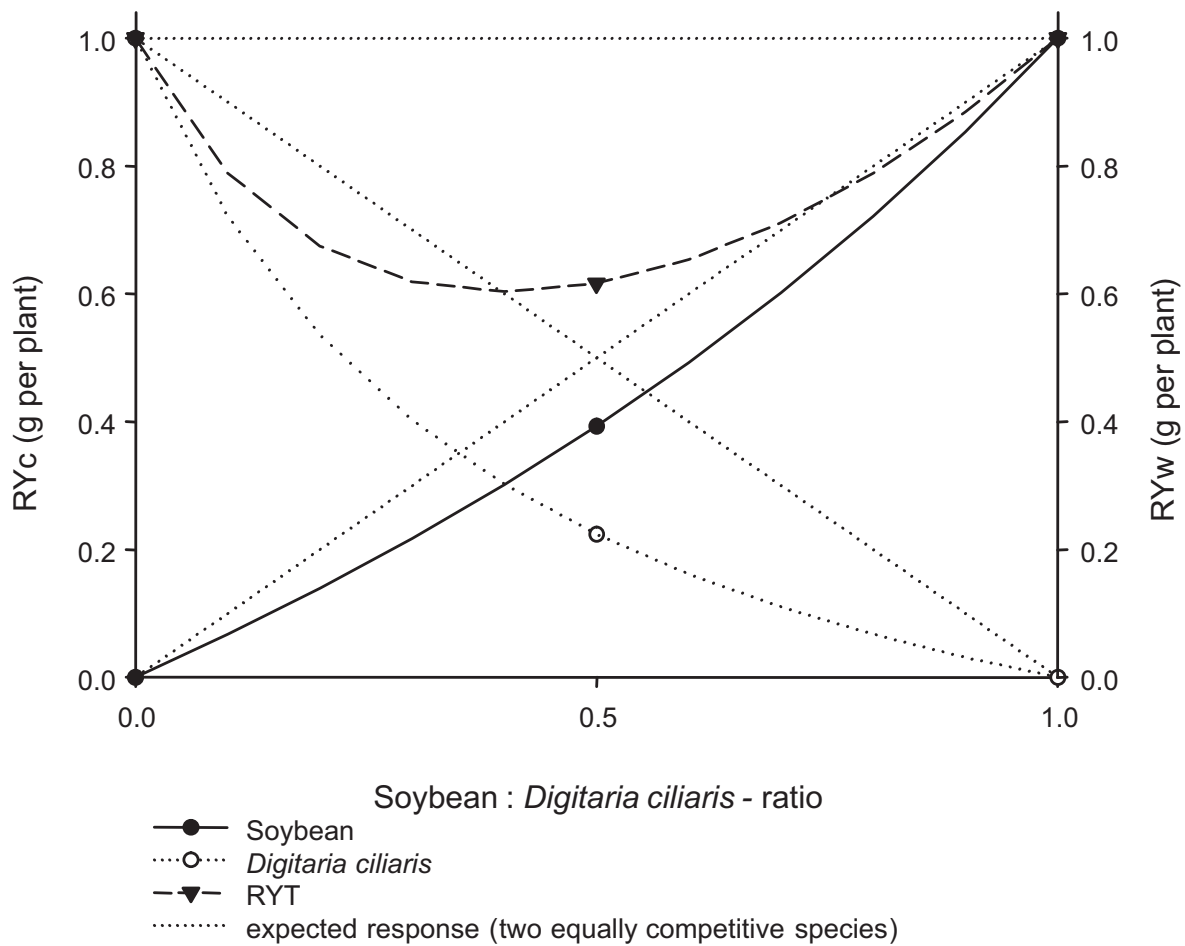

Figure 9 - Relative yields (g dry matter per plant) to crop (RYc) and weed (RYw) as well as relative yield total (RYT) estimated from soybean and Digitaria ciliaris grown under water stress, in monoculture or in competition in a replacement series in a growth chamber. 
Table 4 - Relative yield, relative yield total and cluster coefficients comparisons of soybean and each weed in relation to water stress condition, established between the 20th and 40th days after transplant

\begin{tabular}{|l|c|c|c|c|c|c|}
\hline \multirow{2}{*}{ Coefficient } & \multicolumn{2}{|c|}{ Soybean : A. tenella } & \multicolumn{2}{c|}{ Soybean : T. procumbens } & \multicolumn{2}{c|}{ Soybean : D. ciliaris } \\
\cline { 2 - 7 } & NW & WS & NW & WS & NW & WS \\
\hline RYT & $1.04(0.03)$ & $0.99(0.02)$ & $1.04(0.08)$ & $0.98(0.01)$ & $0.97(0.06)^{*}$ & $0.62(0.04)$ \\
\hline RYc & $0.79(0.03)^{*}$ & $0.73(0.06)$ & $0.84(0.03)^{*}$ & $0.72(0.04)$ & $0.71(0.05)^{*}$ & $0.40(0.03)$ \\
\hline RYw & $0.25(0.02)$ & $0.27(0.05)$ & $0.20(0.08)$ & $0.26(0.05)$ & $0.26(0.01)^{*}$ & $0.22(0.01)$ \\
\hline Kcw & $3.77(0.58)^{*}$ & $2.76(0.77)$ & $5.49(1.44)^{*}$ & $2.56(0.48)$ & $2.59(0.67)^{*}$ & $0.67(0.01)$ \\
\hline Kwc & $0.34(0.03)$ & $0.38(0.09)$ & $0.26(0.14)$ & $0.36(0.09)$ & $0.35(0.02)^{*}$ & $0.28(0.01)$ \\
\hline
\end{tabular}

* Significantly different by $\boldsymbol{t}$ test $(\mathrm{P}<0.1)$, between NW and WS indexes, within each experiment. Values limited by parentheses represent the standard deviation from averages with $95 \%$ confidence. NW: no water stress; WS: water stress. RYc - soybean relative yield; RYw weed relative yield; RYT - relative yield total; kcw - soybean cluster coefficient; kwc - weed cluster coefficient.

observed that these weeds have, in general, tolerance to brief water stress. The competitive relation between soybean and each species changed under water soil content restriction, mainly with $D$. ciliaris. A single factor such as water availability is not enough to predict the interference between species. Future studies should evaluate different levels of water stress and radiation on the root growth of these species, as well as its influence on nutrients extraction from the soil.

\section{LITERATURE CITED}

BRAY, E. Abscisic acid regulation of gene expression during water deficit stress in the era of the Arabidopsis genome. Plant Cell Environ., v. 25, n. 2, p. 153-161, 2002.

COBLE, H. D. et al. Common ragweed (Ambrosia artemisiifolia) interference in soybean (Glycine max).

Weed Sci., v. 29, n. 3, p. 339-342, 1981.

COSTA, L. C. et al. Effect of water stress on the efficiency of capture of water and radiation by soybean. Trop. Sci., v. 39, n. 1, p. 91-97, 1999.

DAYADAY, F. A.; PONS, T. L. The competition of crabgrass Digitaria ciliaris (Retz.) Koel with maize (Zea mays L.) and the possible role of allelopathy. USM Res. J., n. 1, v. 1, p. 1-10, 1978.

De WIT, C. T.; GOUDRIAAN, J. Interference of plants. In: De WIT, C. T.; GOUDRIAAN, J. Simulation of ecological processes. 2.ed. New York: Wiley, 1978. 175 p.

De WIT, C. T. On competition. Wageningen: Institute for Biological and Chemical Research on Field Ccrops and Herbage, 1960. 82 p. (Miscellaneous, 60/68)
FERREIRA, E. A. et al. Estudos anatômicos de folhas de espécies de plantas daninhas de grande ocorrência no Brasil. Amaranthus deflexus, Amaranthus spinosus, Alternanthera tenella e Euphorbia heterophylla. Planta Daninha, v. 21, n. 2, p. 263-271, 2003.

FLEXAS, J. et al. Diffusive and metabolic limitations to photosynthesis under drought and salinity in C3 plants. Plant Biol., v. 6, n. 3, p. 269-279, 2004.

GOWIK, U. et al. Evolution of C4 phosphoenolpyruvate carboxylase in the genus Alternanthera: gene families and the enzymatic characteristics of the C4 isozyme and its orthologues in C3 and C3/C4 Alternantheras. Planta, v. 223, n. 2, p. 359-368, 2006.

GRIFFIN, B. S. et al. The Inflence of water stress on the physiology and competition of soybean (Glycine max) and Florida Beggarweed (Desmodium tortuosum) Weed Sci., v. 37, n. 4, p. 544-551, 1989.

HOLM, L. et al. World weeds: natural histories and distribution. New York: John Wiley \& Sons, 1997. 1129 p.

INAMULLAH; ISODA, A. Adaptive responses of soybean and cotton to water stress. I-Transpirations changes in relation to stomatal area and stomatal conductance. Plant Produc. Sci., v. 8, n. 1, p. 16-26, 2005.

JAMES, A. T. et al. Genotypic variation for drought stress response traits in soybean. II. Inter-relations between epidermal conductance, osmotic potential, relative water content, and plant survival. Austr. J. Agric. Res., v. 59, n. 7, p. 670-678, 2008.

KAISER, W. M. Effect of water déficit on photosynthetic capacity. Physiol. Plant., v. 71, n. 1, p. 142-49, 1987.

KING, C. A.; PURCELL, L. C. Interference between Hemp Sesbania (Sesbania exaltata) and Soybean (Glycine max) in Response to Irrigation and Nitrogen. Weed Sci., v. 45, n. 1 p. 91-97, 1997. 
LÓPEZ OVEJERO, R. F. et al. Growth and competitiveness of biotypes of crabgrass resistant and susceptible to acetyl coenzyme A carboxylase inhibiting herbicides. Pesq. Agropec. Bras., v. 42, n. 1, p. 1-8, 2007.

McCOY, E. L. et al. Net carbon allocation in soybean seedlings as influenced by soil water stress at two soil temperatures. Bot. Gaz., v. 151, n. 4, p. 497-505, 1990.

NISENSOHN, L. et al. Biological factors determining Commelina erecta competition with other weeds in cultivated systems. Planta Daninha, v. 29, n. 1, p. 97-106, 2011.
PIKE, D. R et al. Modelling soybean growth and canopy apportionment in weed-soybean (Glycine max) competition. Weed Sci., v. 38, n. 6, p. 522-527, 1990.

RICE, E. L. Impact of allelopathy in agricrop;

Allelopathy. Oklahoma: University of Oklahoma, 1974.

$196 \mathrm{p.}$

WILSON, J. R. et al. Rapid response to shoot removal by the invasive wetland plant alligator weed (Alternanthera philoxeroides). Environ. Exper. Bot., v. 60, n. 1, p. 20-25, 2007. 